\title{
COPING STRATEGIES AMONG INFORMAL SECTOR WORKERS OF MICRO ENTERPRISES: A CASE IN THE CIBURIAL VILLAGE OF KECAMATAN CIMENYAN, BANDUNG DISTRICT
}

\author{
Eri Susanto \\ Bandung Social Welfare Polytechnic, erisusanto@poltekesos.ac.id \\ Fachry Arsyad \\ Bandung Social Welfare Polytechnic, fachryarsyad@gmail.com
}

\begin{abstract}
Coping strategy among informaal sector workers of micro enterprises is motivated by the problem of workers in the informal sector that generally have very low income levels. In addition, micro-scale informal sector workers also do not have social protection, and are vulnerable to work safety such as tire patching, road vendors, roadside stalls, and parking attendants. This study aims to describe the coping strategy undertaken by workers in the informal micro enterprises sector which includes characteristics, emotionals and problems focused coping. The research method used is a qualitative descriptive method with case studies of tire patch workers, food stall waiters and parking attendants. The informants in this study consisted of 3 (three) main informants and 3 (three) supporting informants. Data collection techniques use interview, observation and documentation study. The results of the study use qualitative data analysis. Data were tested through perseverance of observation, extension of participation, triangulation and reference material. The results showed that the coping strategy undertaken by informal sector workers of micro enterprises in handling the problem was not good enough. The emotional focused coping aspect carried out by the informants was more accepting / resigned, thus affecting the problem focused coping, i.e. there was no planning to find a solution to the problem, less initiative. The action is more about asking for help, borrowing money, that does not solve the problems they are experiencing.
\end{abstract}

\section{Keywords:}

Coping strategy; workers of informal sector; micro enterprises; emotional and problem focused coping. 


\section{INTRODUCTION}

Poverty is an issue that continues to be a main concern in various discourses of social problems or social (welfare) development, especially in Indonesia. Workers in the informal sector are one of the jobs that are vulnerable to various social vulnerabilities, in other words, they fall into a cycle of poverty. This is based on the fact that informal sector workers, apart from getting a small wage or remuneration, are also based on more trust, do not have certainty in their career and income for their future, and are generally not legally incorporated.

Based on Law no. 25 of 1997 concerning Manpower, informal sector workers are workers who work in the informal sector work relationship and receive wages and / or remuneration. The work relationship between informal sector businesses and their workers is only based on mutual trust and agreement by receiving wages and / or compensation or profit sharing (Purnamasari, 2016). Meanwhile, Law No.13 of 2003 concerning Manpower, does not regulate informal sector workers. In addition, what is meant by labor in Law no. 13 of 2003 is any person who is able to do work that produces goods or services, both to meet their own needs and to the community [Article 1 paragraph (2)].

Based on that explanaation, workers who do not have the appropriate qualifications determined by a company or government agency, they tend to choose a job outside the formal sector. Furthermore, they are considered to as informal sector workers. The term informal sector was first put forward by Keith Hart (Hart, 1973) who stated that the informal sector is part of the urban labor force that is outside the organized labor market. In general, workers in the informal sector are in Micro, Small and Medium Enterprises (MSMEs).
Meanwhile, the number of MSMEs dominates the employment field rather than large businesses.

According to data from the Indonesian Ministry of Cooperatives and MSMEs, the MSME sector contributed 61.41\% GDP (Gross Domestic Product), labor absorption of $96.71 \%$, and exports of $15.73 \%$ in the non-oil and gas sector. (KemenKop \& UKM, \& BPS, 2015). Judging by the number, MSMEs also continued to increase in Indonesia, starting from 2014-2016 the number of MSMEs was more than 57,900,000 units and in 2017 the number of MSMEs was recorded as $59,267,759$ micro enterprises units or around $98.74 \%$, small enterprises of 681,522 units or $1.15 \%$; medium-sized enterprises of 59,263 units or $0.10 \%$; and large enterprises of 4,987 units or $0.1 \%$. (Kemenkop \& UKM, 2014-2017).

Seeing the growth in the number of MSMEs that continues to increase, most of them are still doing business in the informal sector (TNP2K, 2015). From the number of MSMEs, micro enterprises absorb the largest number of workers, namely $87 \%$ are in micro enterprises, $5.7 \%$ small enterprises, $4 \%$ medium enterprises, and large enterprises 3.3\% (Bank Indonesia, 2016). This shows that the largest number of workers in MSMEs is absorbed by workers in the informal sector. Meanwhile, the sector has many problems that must be resolved, starting from licensing, orderliness, security, and of course the welfare of its employees.

Behind the huge contribution of the UMKM business sector to the economy, ironically there are still many problems that must be faced by MSMEs in order to survive and develop. Common problems faced to date include: having limited access to financial institutions, difficult licensing arrangements due to very complicated bureaucracy, and limited human resource 
capacity. Another problem also comes from the characteristics of the MSMEs themselves, which in general, both owners and workers in the MSME sector, have a low educational background, and most of a person's motivation to make an UMKM is based on economic pressure (poverty), not from an entrepreneurial spirit (Nurhalim, 2014).

Furthermore, looking at the welfare side of its workers, especially in the small and micro enterprises (SMEs) sector, there is a separation between paid and unpaid workers, where there are 6.54 million people $(60.63 \%)$ who are unpaid workers because they are owners and families, and 4.24 million people $(39.37 \%)$, are paid workers. From the workers who are paid wages, most earn less than 10 thousand rupiah per worker per hour. The number of SMEs under this category reached 929.37 thousand enterprises (67.94\%). Meanwhile, SMEs with wages between 10 thousand and 19 thousand amounted to 361.88 thousand $(26.46 \%)$ and enterprises with remuneration of more than 20 thousand rupiah per worker per hour were 76.74 thousand (5.61 percent) (BPS, 2017). Taking into account these data, the level of welfare of workers is very low and is not protected by various social security, even very vulnerable to safety such as tire repairing business and traveling traders.

This certainly affects the welfare level of workers of small and micro enterprises, because if calculated per month, the average income of the majority of workers in this sector is below 1.6 million rupiah per month, far below the average regional minimum wage in Indonesia which is in the range of 1,9 million rupiah per month (BPS, 2016). Apart from that, looking at social protection side, there are still many micro and small enterprises workers who enter the informal sector, are not protected by social security either from social security for labor, health, or pensions.

Informal workers still face many problems ranging from low wage levels, which causes them to experience stress, because they are unable to pay for children's schools and pay their debt obligations (ILO, 2015). Moreover, the absence of social protection or health insurance also makes workers in this sector vulnerable in terms of occupational health and safety. From the complexity of the welfare problems faced by informal workers, it is interesting to examine the coping strategies carried out by these informal workers in dealing with their problems, both internally by the informal workers themselves, and externally in the form of support from other parties in helping to deal with problems that are faced by the informal workers.

One of the studies that discusses the conditions of workers in the informal sector was conducted by Tri Sulistiyono (2015), entitled Study on the Informal Workers Welfare in Micro Small Business in Gunung Pati District of Semarang Examined Under The Act No. 13 of 2003 on Man Power. The study tried to explain the definition of informal workers and their relationship with labor laws, the level of welfare of informal workers in business places in Gunungpati Regency which is studied based on the provisions of Law No. 13 of 2003, and the minimum wage standard in Semarang City.

In addition, this study also explained the working relationship between informal workers and business owners in business places in Gunungpati Regency, starting with an oral agreement between the two parties regarding the work to be carried out by workers, their wages to be earned and the time of payment. Wages that were previously received by workers were in accordance with the capabilities of the 
business owner. Wages are given daily, weekly, or monthly.

The results of the study also show that welfare for informal workers, when adjusted to Law No.13 of 2003, is almost completely inconsistent with the provisions of the law. Starting from the amount of wages that are still below the minimum wage for the City of Semarang, working time exceeds the provisions for working time without overtime payment, other aspects of welfare such as lack of certainty in the health aspect in terms of medical reimbursement, Religious Holiday Allowances are also not in accordance with the regulatory provisions.

The conditions experienced by informal sector workers cause them to be far from the level of welfare as well as having social vulnerabilities that will become problems, such as loss of work or income, stress and lack of fulfillment of their basic needs, low level of security that can threaten the safety of their lives. Those problems are what will make them try to find how to solve the problems they face.

Everyone who has a problem as described above will try to solve it to get out of the problem, in other words, that person will do a copyng strategy. Matheny, et al (1992) in Triantoro and Nofrans (2009) explain that coping is any effort, healthy or unhealthy, positive or negative, conscious or unconscious efforts, to prevent, eliminate, or weaken stressors, or to provide resistance to the effects of stress. Levine in Garmezy and Rutter (1983) in Sutaryadi (2009: 24) states that coping is an active process that occurs due to efforts to adapt to environmental conditions that contain a lot of stress. While the aspects contained in coping according to Lazarus and Folkman (1984) in Triantoro and Nofrans (2009) are the first aspects focusing on emotions, where an individual attempts to control an emotional response to a pressing problem. second, the aspect focuses on the problem, where the efforts made by individuals to reduce problems that suppress it by learning new ways or skills to be used in changing situations, circumstances, or the subject matter.

Based on the large phenomenon in society regarding workers in the informal sector of micro enterprises and the concept of how to solve problems, this research becomes important. In general, this research wants to know how the coping strategy for workers in the informal sector of micro enterprises in facing problems, especially to meet their needs in Ciburial Village, Kecamatan Cimenyan, Bandung District. The choice of this place is because Ciburial Village is one of the tourist destinations where there are quite a lot of informal sectors, especially food stalls, tire patch businesses, and parking areas.

The primary purpose of the study was to identify the common coping strategies that informal sector workers deal with their problem solving especially to fullfill mnimum needs. As for the research questions of this study are: 1) What are the characteristics of the research informants?; 2) How are the informants' efforts to deal with emotions in pressing situations in order to fulfill their basic needs, including seeking social emotional support, distancing, escape avoidance, self control, accepting responsibility, and positive appraisal); 3) How are the informants' efforts in solving problems through real efforts made which include seeking informational support, confrontive coping, and planful problem solving); and 4) What are the expectations of workers in the informal sector of micro enterprises in Ciburial Village, Kecamatan Cimenyan, Bandung District in conducting a coping strategy.

This research is expected to be able to help workers in the informal sector of 
micro enterprises in understanding how coping strategies can be done in solving the problems they face, especially those related to emotional control and problem solving planning. This is because every worker in the informal sector has his/her own way of dealing with problems. Researchers have high hopes for workers in the informal sector to be able to carry out a coping strategy according to their abilities. Therefore, the result of this study is expected to be able to provide benefiits both for the research itself and for informal sector workers of micro enterprises.

\section{METHODS}

Research on coping strategy for workers in the informal sector of micro enterprises is to find out aspects related to worker characteristics, emotional focused coping, problem focused coping and expectations of copying strategy in order to meet basic needs for informal sector workers in the Ciburial Village Kecamatan Cimenyan, Majalengka District. Therefore, this research was conducted using a descriptive qualitative approach with case studies on tire repair workers, food stall employees, and parking attendants. Based on this approach, researchers will get an indepth picture of how the coping strategy of workers in the informal sector of micro enterprises. Researcher chose descriptive qualitative methods to be able to make a complete and detailed description of the research subject.

The research was carried out in Ciburial Village, Cimenyan District, Bandung Regency, which is one of the natural tourist areas which then also attracts the informal sector of micro enterprises to get income which in turn attracts workers, such as street vendors, food stalls, coffee shops / cafes, tire repairing businesses, as well as parking attendants.
The data collection technique carried out in this study used, namely:

1) Observation technique (observation), which is a way of collecting data by systematically observing and recording the phenomenon being investigated, or problems related to the research carried out. In this case those related to the condition of tire patch workers, parking attendants, and waitress; the level of social welfare; and what programs or assistance was provided. Observations used in this study are semi-structured observation, in which the researcher previously knew what aspects of the activity would be observed and were relevant to the problem and the research objectives and then developed in depth.

2) In-depth interview technique, which is how to collect data through questions and answers or asking for direct explanations, where at first asking a series of structured questions using interview guides from various parties related to the object of research, then deepened by digging further. These interviews were conducted with either the tire patch worker, the owner of the tire patch business, or the local government or organizations related to social welfare programs.

3) Documentation Study Techniques. Documentation studies are carried out by studying from various sources such as books, magazines, researches or other written literatures. The documentation results were selected and adjusted to this research needs.

Data analysis was carried out by organizing data, describing them into units, synthesizing, arranging into patterns, choosing which ones are important and what will be studied, and then making conclusions (Sugiyono, 2007: 224). The validity of the data is tested by using data testing 
techniques which include: 1) the degree of trust (credibility), which is to prove that the data collected is in accordance with the actual conditions; 2) confirmability, namely testing the results of the research in relation to the processes that have been carried out; 3) dependability, that is, this research is directed and conducted seminar by the Bandung Poltekesos Research Center from the beginning to the research report; 4) transferability, namely by providing a detailed, clear and systematic description to show the extent to which research results can be used in other situations that have the same characteristics; and 5) Triangulation, namely as a means of testing the accuracy of research by checking data from various sources, places and different times.

\section{RESULT AND DISCUSSION Characteristics of Respondents}

Research on the coping strategy of workers in the informal sector in Ciburial Village, Kecamatan Cimenyan, Bandung District, namely workers on tire patches business, food stall worker, and parking attendant. The informants in this study were 6 people consisting of 3 (three) informal workers and 3 (three) family members or employers, or trusted people of the informal workers. The following are informants who provide information regarding the coping strategy of workers in the informal sector in Ciburial Village.

The characteristics of the informants are important to convey because they can affect how he or she performs a coping strategy. Billing and Moos (1984) said that the factors of age, gender, socioeconomic status, emotional awareness, level of education and physical health will affect the tendency of using coping strategies. In this study, different characteristics were selected in terms of age, sex, and also the type of work in the informal sector.

Matrix 1.1 Research Informants of Coping Strategy of Workers in the Informal Sector in Ciburial Village, Cimenyan District, Bandung Regency

\begin{tabular}{|c|c|c|c|l|l|}
\hline No. & Name & Age & M/F & Pekerjaan & $\begin{array}{l}\text { Statu } \\
\text { s }\end{array}$ \\
\hline 1 & AP & 44 & M & $\begin{array}{l}\text { Tire Patch } \\
\text { Worker }\end{array}$ & Married \\
\hline 2 & RN & 23 & F & Waitreess & $\begin{array}{l}\text { Not- } \\
\text { Married }\end{array}$ \\
\hline 3 & KH & 38 & M & $\begin{array}{l}\text { Parking } \\
\text { Attendant }\end{array}$ & Married \\
\hline 4 & UJ & 39 & M & $\begin{array}{l}\text { Brother- } \\
\text { in-law }\end{array}$ & Married \\
\hline 5 & HI & 56 & F & $\begin{array}{l}\text { food stall } \\
\text { owner }\end{array}$ & Married \\
\hline 6 & YI & 36 & PIF & $\begin{array}{l}\text { Parking } \\
\text { Manager }\end{array}$ & Married \\
\hline
\end{tabular}

Source: Research Interview Result, Year 2020

In detail, the characteristics of research informants are described as follows.

\section{Informant AP}

Informant AP is a head of household who has been married 23 years ago and has 3 (three) children. The children are 2 (two) girls and 1 (one) boy. He lives together with his parent in one house in the attic of that house in Ciburial Village. He works as a tire repairman with average daily income is about Rp. 45,000.00. The business itself is owned by his parents. It is because that all the capital comes from them.

This income must be able to be shared for his parents and his brother and sister 
although given freely without a limit on the number. The money is given sometimes once a month in the amount of Rp. 100.000,-. The job has been done for more than 10 years and operates on Jalan Dago - Cigadung Bandung. which is quite busy with vehicles. There are 2 (two) reasons why he will not chnage his job now. First, with his age, it is very difficult ti find a job in a formal sector. Second, He has no other skill except in tire patch business.

\section{Informants $\mathrm{RN}$}

Informant $\mathrm{RN}$ is originally from Garut, a city in west java province. She is a worker at a rice stall. She works as a waitress to serve customers. She gets the job from an acquaintance of her father who owns a rice stall in Bandung, where located in front of a hotel area in Ciburial Village. She works for 8 hours from 08.00 until 17.00 hours afternoon. She is given a wage of Rp. 30.000 per day. Other than that, she gets a free lunch and also a boarding house for free as long as she works in there. Nevertheless, according to her opinion, her income does not fullfil her need entirely yet and is still difficult to save money in order that it can be used for other needs or to open a new business in the future. Until right now, she also still hopes to find a suitable and better job.

\section{Informan $\mathrm{KH}$}

Informant $\mathrm{KH}$ is a parking attendant located in a area of a rice stall. He comes from Banjar West Java. He has been married dan has 2 (two) children. The average income earned is Rp. 1.5 million per month. Various types of work have been carried out to meet the necessities of life for his family, ranging from salesman, traveling ice seller, opening stall, construction worker, and now parking attendant. He is quite ambitious and optimistic that in the future he will have a suitable and better business. Informam $\mathrm{KH}$ is trying hard to save money as could as possible, so he can run business independently someday in his hometown, in Banjar.

\section{Informants UJ}

Informant UJ is the brother-in-law who owns kiosk stalls business and located in the same land/area with AP's tire patches businness. UJ and his wife, AP's younger brother, opened a sidewalk shop/kiosk stall that provides drinks, cigarettes, coffee and some daily necessities such as bath soap. UJ knows AP very well because almost every day they meet and they also help each other, for example opening motorbike / car tires, or vice versa, someone buys at UJ's shop while they have other needs to leave the shop so that they can be deposited.

\section{Informants $\mathrm{HI}$}

Informant $\mathrm{HI}$ is the owner of a rice stall in the tourist complex area and in front of a hotel that provides various types of allround Sundanese cuisine. The distinctive taste of Sundanese and complete makes this business always quite crowded with buyers, most of whom bring private vehicles. The HI's informant employs YN, who has worked there for almost two years. I know YN because from his father who also knows each other, who used to be from Garut but has now settled in Bandung by opening a rice stall which is quite successful.

6. Informant YI 
Informant YI is the son of a food stall owner who helps his parents and is given the responsibility of providing services to his customers, including a parking area which is quite decent to manage. YI' informants show $\mathrm{KH}$ in the parking lot so that their customers' vehicles can be neatly arranged. YI informants can provide $\mathrm{KH}$ an income of 1.5 million per month on average.

\section{Emotional Focused Coping}

Emotionally focused coping shows a reaction to the emotional aspects that they face. There are 6 (six) aspects measured, which include: 1) seeking social emotional support; 2) distancing, 3) escape avoidance 4) self control 5) accept responsibility, and 6) possitive reappraisal.

The five aspects were carried out by the informants in their coping strategies in relation to emotional focused coping. In the aspect of seeking social emotional support, on the whole, the informants received support in the form of advice or suggestion. The advice is got from people who were emotionally close to them. In other words, the advice come from people considered to be able to be trusted, such as from family, relatives, close friends or their employers. Support in the form of assistance helps informants in making decisions dan problem solving. This is because people who have problems generally experience difficulties in making decisions.

This emotional support can provide reinforcement in order to reduce the burden on informants. In addition, informants did not feel alone in facing the problems they were experiencing. This is because informants feel happy to be heard and cared for by the people around them. Informant AP prefer his friend to pour out his feelings or burdens instead of their family or siblings. Informant $\mathrm{RN}$, because she was a migrant from Garut and did not have many friends, he told the burden to the daughter of her employer.

She helped his parents manage the rice stall. While $\mathrm{KH}$ is more open than the other 2 (two) informants He often shares his feeling or problems to his employer or parking manager. He got a lot of valuable input to make a decision in his life. Aside from that, $\mathrm{KH}$ also shares the burden or problem to his wife to make decisions together.

In the aspect of distancing, the three respondents indicated that they were trying to get out of the problems they were facing. They realize that their job have not been able to provide a good guarantee for family livelihoods in the present and in the future. However, the three of them said that they were pragmatic about their life with doing the job they have now. They also try hard to save money to be able to get job appropriatly someday in the future, or to open their own business. This is as stated by Mechanic (1974) thay copyng strategy aims to agree on our desires with existing environment.

The third aspect of emotional focused coping is escape avoidance. In this aspect, the informants have almost the same reaction among them. they try not to avoid the various difficult situations they face. In other words, they face their problems as a part of their life that must be solved. They all also stated the same statement that avoiding the problem will not solve the problem. On the contrary, it will add to the 
problem or it can make condition worse. This is as stated by Lestari (2015), that coping is a self effort aimed at sources of stress that cause unpleasant emotions.

Informant $\mathrm{RN}$ is more resigned to accept his condition, including his job as a waiter at a rice stall. "Being able to work here is grateful," she said. While KH prefers to be passionate about working regardless of his type of work, even though he is a parking attendant. However, he is trying to be able to save money and also trying to get a better income in the future. He has a dream of opening his own business in his hometown, in Banjar - West Java. Meanwhile, AP states that patching tires is the skill that he has now, no other one. he just hopes to have his own business and add his business more.

In the self-control aspect, informants prefer to be patient for their self-control rather than complain about the situation they were experiencing. Apart from that, the informants also took a religious approach by praying so that they hope to get always good fortune and health from God. By praying and surrendering to God, it can help in controlling oneself so that they are always patient with the situation, not angry and regretting the life they have lived. In addition, other activities besides praying / worshiping, in the context of self-control are to express the problem with someone who can be trusted and can give advice to him. This is felt to reduce the burden or stress of life unpleasant emotions. Mc Crae and Costa (Carver, etc., 1989) stated that people tend to turn to religion when under stress for various reasons, as a means of positive reinterpretation and growth.

Furthermore, in the aspect of accepting responsibility, the informant showed an attitude of acceptance of the situation towards the problems experienced, especially in meeting the needs of life. The attitude of acceptance is considered better because at this time they still has not got a better job or business than what he is getting right now. The only one way that is considered best is to accept circumstances in order to do or run their job well. This shows that they actually are not satisfied with the type of work they are doing, nevertheless do not have a better occupation / income.

The last aspect is possitive reappraisal. In this aspect, the informant's assessment of the situation and condition of the problem they were experiencing is a state of destiny that must be lived. This assessment shows that they accept or surrender with a state of their work in the informal sector. Although this condition is considered as destiny, they still hope for a better job and life on their mind. They seem quite resilient to the current conditions. These patient individuals usually use active and effective coping strategies (William, etc. in Taylor, 1995)

\section{Problem Focused Coping}

In Problem Focused Coping, there are 3 (three) aspects that are asked of informants related to coping that focus on problems, including: 1) seeking information support, 2) confrontative coping, and 3) planful problem solving. In the aspect of seeking informational support, informants seek information in solving problems through their closest friends, employers and family. They assess the importance of the information provided by the person to ask as part of the problem solving. Information 
obtained by informants from close / trusted friends, family, and employers generally takes the form of advice. Other information is about sources that are considered to help solve problems, for example a bank that provides loans / credit and how to loan to the bank both for meeting basic needs such as food, education and health, as well as for business capital.

The information support felt by the informants was considered to have an important meaning in helping to alleviate or solve problems that were a burden so that informants need people who are considered appropriate as places to express their problems who can then provide information related to the problems they face. The problem for informants is a very personal matter, therefore it is not necessary for other people to know about it, but only certain people who can be trusted, whether friends, family or employers or colleagues who have the same type of work.

The second aspect is confrontative coping, solving problems in a concrete manner. Efforts made by informants, especially those who are married (AP and $\mathrm{KH}$ ) in meeting the needs of the family, because they have a larger need, is to borrow money from the bank or family. This is because the informants' income is not even far below the Bandung Minimum Wage of Rp. 3,623,778 (SE Number: 561/75 / Yanbangsos). The informants felt that they had no other choice except to borrow money. This is because of family needs that had to be met, such as food, clothing, shelter, education and health.

The informants realized that borrowing money was a hard choice and did not guarantee that it would solve the problems. Informants have to pay interest, especially when borrowing from a bank, and they realize that this is also a bigger and riskier problem. However, when the need is urgent, there is no more choice.

The third or last aspect of problem focused coping is planful problem solving, which is analyzing every situation that causes problems and trying to find solutions directly to the problems. The three informants saw their situation as a fate that had to be accepted. The problems they experience are understood as a condition of inability with limitations in terms of education, skills and capital. Thus, the informant did not analyze the situation which became the cause which in turn would be difficult to solve the problem.

\section{DISCUSSION}

Based on the results of research conducted on informants who work in the informal sector of micro interprises in Ciburial Village of Kecamatan Cimenyan, Bandung District, the coping strategy that is dealt with by the informal sector workers can be said to be less able to do well with the problems faced, especially in meeting basic needs. This can be seen from the two processes of coping factors that were asked to informants, namely emotional focused coping and problem focused coping in response to the problem (Lazarus and Folkman in Safaria, 2012).

Based on research conducted on informal sector workers in micro enterprises in Ciburial Village, informants have a coping strategy that is relatively similar in dealing with various pressures from the problems they face, namely acceptance of living conditions, especially work. Informal 
sector workers are wage earners to solve their problems in meeting basic needs both for themselves and their families. This acceptance is a part of coping that is an avtive process that occurs due to efforts to adapt to enviromental condirions that contain a lot pressure (stress) (Levine in Sutaryadi, 2009).

The coping strategy that is shown by each person has its own characteristics but in general it has similarities in overcoming problems such as similarities in obtaining support from others in the form of advice, accepting or surrendering to the circumstances that occur, not avoiding the problems they are experiencing but also not making efforts optimal to get out of the problem, be patient in the sense of resigning / accepting and carrying out religious activities by praying, and considering that the work or the problems he is experiencing is considered as a fate or destiny that must be lived.

Likewise with problem focused coping, the information obtained are: in the form of advice, the lack of money to meet basic needs by way of borrowing money, and the lack of problem analysis to solve their problem.

Based on these problems, it can be seen that some of the needs that are needed, namely:

1. There is strengthening in emotional focused coping, where informants who work in the informal sector of micro enterprises (micro enterprises) do not just surrender to their fate or problems, but there must be a strong motivation to be able to solve the problem. This strengthening can be done through counseling, so that they can have a strong motivation to not only be willing or accepting but also continue to try to get out of their problems by looking for information to increase their ability to produce a better job / business opportunity.

2. The role of various parties (stakeholders) is needed very much. They are from from family, local community, regional or local government to provide services to people who are less able to fulfill their basic needs and increase the capacity of skills or business capital. For example, the distribution of assistance for the Family Hope Program (PKH), Joint Business Group (KUBE), and credit assistance. This is very possible considering that the informant is still relatively young and has the potential to be given skills training to improve his quality of life.

No less important is community empowerment process by using appropriate community development technology such as social mapping technology, methodology for participatory assessment (MPA), venn diagram technology for social mapping, technology of participation (ToP), and participatory monitoring and evaluation technology (Susilowati, 2019).

The needs felt by informal sector workers at these micro enterprises are increased basic needs and self-potential through skills training, joint business groups, and access to finance or capital. Based on these needs, the source systems that can be utilized are informal, formal and social sources. Informal sources that can be used are: 1) family, which is the closest person emotionally who will generate support for 
informants; 2) neighbors and / or friends who are emotionally close can also provide support, be it advice, affection or other assistance to informants in dealing with pressure problems so that they do not feel alone.

In formal sources, informants can be given direct services where informants can then benefit from these services, among others, 1) The social service can include them in the Family Hope Program (PKH). The Department of Manpower can provide employment training. Meanwhile, the UMKM Office can also provide access to joint business groups or access to finance / capital; 2) Kelurahan Ciburial can provide facility for the KUBE service program or skills training so that it is close to the workplace. Meanwhile, social sources that can be used by the informants are places of worship, quite a lot of recreational parks, health facilities, as well as state-owned or private enterprises.

\section{CONCLUSION}

Informal sector workers have a low level of income, far below the UMK, which results in a lack of fulfillment of their basic needs, including food, children's education and health. Informants in coping strategies related to the problems of their work as informal sector workers are similarities in obtaining support from advice, accepting the situation that occurs, not avoiding problems but also not making optimal efforts to get out of their problem, being patient in the sense of resignation and only pray but do not know what to plan, and consider that the work or the problems they are experiencing are considered a fate or destiny that must be lived.
Based on the results of this study, the needs of informants in addressing basic needs fulfillment by means of coping strategies are as follows:

1. Emotional support from trusted close people, whether family, friends, neighbors or employers.

2. Services to improve basic needs and self-potential in the form of social assistance, as well as services that increase self-potential (capacity building) in the form of skills training, KUBE, financial access.

The sources that can be used in order to fulfill the needs of informants at first are the informal sources such as family, neighbors, close friends or employers. The second are formal sources that include, among others, the social service, the manpower office, and the UMKM office. And the thitd are social sources, such as places of worship, recitation groups, and community organizations.

\section{REFERENCES}

Ayyagari, M., T. Beck, and A. DemirgucKunt. 2007. Small and Medium Enterprises across the Globe. Small Business Economics 29 (4), 415-434.

Bank Indonesia (2015) Business Profile of Micro, Small and Medium Enterprises. Cooperation between the LPPI and Bank Indonesia

BPS (2015) Profile of Micro and Small Industries 2015. Jakarta. BPS RI

BPS (2015) Profile of Micro and Small Industries 2015. Jakarta. BPS RI

BPS (2017) Profile of Micro and Small Industries 2017. Jakarta. BPS RI

Briozzo, A. and Cardone-Riportella, C. (2012). Evaluating the Impact of Public Programs of Financial Aid to SMEs during times of crisis: The Spanish Experience (No. 12.04).

Carver, CS., Scheir, M.F., \& Wientraub, J.K (1989). Assesing Coping Strategy: A 
Theoritically Based Approach. Journal of Personality and Social Psychology . Vol. 56. No. 2 , 267 -283.

Chowdhury, S. R. (2011). Impact of global crisis on small and medium enterprises. Global Business Review, 12 (3), 377399.

Chusho Meti (2013). Japan's Policy on Small and Medium Enterprises (SMEs) and Micro Enterprises, accessed 27.03.2019, http://www.chusho.meti.go.jp/sme _english / outline / 04/2013 100 7.pdf.

Dartanto, Teguh \& Nurkholis. (2013). The determinants of poverty dynamics in Indonesia: evidence from panel data, Bulletin of Indonesian Economic Studies, 49: 1, 61-84.

Kementerian Kperasi dan Usaha Kecil dan Menengah RI. Data UMKM: http://www.depkop.go.id/ data-umkm.

Gagliardi-Main, D., Muller, P., Glossop, E., Caliandro, C., Fritsch, M., Brtkova, G. \& Ramlogan, R. (2013). ANNUAL REPORT ON EUROPEAN SMEs 2012/2013: A recovery on the Horizon? .SME Performance Review.

Mechanic. (1974). Personal Coping. London. Greenwood Publishing Group.

Muller, P., Gagliardi, D., Caliandro, C., Bohn, N. U., \& Klitou, D. (2014). Final Report-July 2014.

Nurhalim, Yunilla, 2014, Reforming Small and Medium Enterprises (SMEs) in Indonesia: Proposal of a New Legal Entity, Thesis International Business Law, Netherlands: Tilburg University.

OECD (2014a). Financing SMEs and Entrepreneurs 2014: An OECD Scoreboard, Paris: OECD Publishing.

OECD (2014b). Entrepreneurship at a Glance 2014, Paris: OECD Publishing.

Rustanto, Bambang. (2015). Qualitative Social Work Research. Bandung: PT Remaja Rosdakarya.

Suharto, Edi, \& Azman, Azlinda. (ed). 2011. Education and Social Work Practices in Indonesia \& Malaysia. Blue Ocean. Yogyakarta.
Susilowati, Ellya. (2019). Penerapan Teknologi Pengembangan Masyarakat pada Program Desa Sabilulungan. Jurnal Ilmiah Perlindungan \& Pemberdayaan Sosial. Vol. 1 No. 1 Tahun 2019. Politeknik Kesejahteraan Sosial Bandung

Sutaryadi. (2009). Stress and Coping. Bandung: Depsos RI BBPPKS Bandung.

Titik, Lestari (2015). Kumpulan teori untuk Kajian Pustaka Penelitian Kesehatan. Yogyakarta: Muha Medika.

Wymenga, P., Spanikova, V., Barker, A., Konings, J. and Canton, E. (2012), EU SMEs in 2012: At the Crossroads. Annual Report on Small and Mediumsized Enterprises in the EU, 2011/12, Report for the European Commission.

https://swa.co.id/swa/profile/profileentrepreneur/umkm-di-indonesia-masihber Moves-di-sektor-informal 